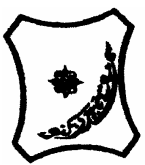

\title{
ANTIMICROBIAL PROFILE OF MORINGA OLEIFERA LAM. EXTRACTS AGAINST SOME FOOD - BORNE MICROORGANISMS
}

\author{
${ }^{* 1}$ Bukar, A., ${ }^{2}$ Uba, A. and ${ }^{1}$ Oyeyi, T.I. \\ ${ }^{1}$ Department of Biological Sciences, Bayero University, P.M.B. 3011, Kano, Nigeria \\ ${ }^{2}$ Biological Sciences Programme, Abubakar Tafawa Balewa University, Bauchi, Nigeria \\ *Correspondence author: al amsak2004@yahoo.com
}

\begin{abstract}
The chloroform and ethanol extracts of seeds and leaf of Moringa oleifera were investigated for antimicrobial activity against some selected food - borne microorganisms as a first step in the screening of the extracts for preliminary sanitizing/preservative properties on foods. The preliminary phytochemical screening and antimicrobial assay were carried out using standard procedures. The results of the phytochemical analysis revealed differences in the presence of the phytochemicals among the extracts. Saponins were detected in all the extracts while tannins were only detected in Moringa oleifera leaf chloroform extract. The antibacterial assay results show that M. oleifera leaf ethanol extract exhibited broad spectrum activity against the test organisms with Escherichia coli, Pseudomonas aeruginosa, Staphylococcus aureus and Enterobacter aerogenes susceptible. The MIC values ranged between 2.0 and $>4.0 \mathrm{mg} / \mathrm{ml}$ for all the organisms. M. oleifera seed chloroform extract was only active against $E$. coli and Salmonella typhimurium. The MIC values ranged between 1.0 and $>4.0 \mathrm{mg} / \mathrm{ml}$ for the tested organisms respectively. Antifungal activity result revealed $100 \%$ inhibition in growth of Mucor and Rhizopus species by M. oleifera seed chloroform extract at concentration of $1 \mathrm{mg} / \mathrm{ml}$. Standard Ketoconazole (control) inhibited the test organisms by $100 \%$ at $0.5 \mathrm{mg} / \mathrm{ml}$ concertration. The result of this study have shown the potentials of M. oleifera extracts as sanitizers/preservatives by inhibiting the growth of the test organisms, which range from food - borne pathogens to spoilage causing organisms in foods.
\end{abstract}

Keywords: Moringa oleifera, Seed, Leaf, Antimicrobial, Phytochemistry, Sanitizer, Food

\section{INTRODUCTION}

Moringa oleifera Lam (Moringaceae), native to the western and sub - Himalayan region, India, Pakistan, Asia minor, Africa and Arabia (Somali et al., 1984; Mughal et al., 1999) is now distributed in the Philippines, Cambodia, Central, North and South America and the Caribbean Islands (Morton, 1991). $M$. oleifera is a tropical tree whose numerous economic applications and facility of propagation are arousing growing international interest. The Moringa tree is cultivated and use as a vegetable (leaves, green pods, flowers, roasted seeds), for spice (mainly roots), for cooking and cosmetic oil (seeds) and as a medicinal plant (all plant organs) (Rebecca et al., 2006).

Moringa oleifera is a highly valued plant, distributed in many countries of the tropics and subtropics. It has an impressive range of medicinal uses with high nutritional value. Different parts of this plant contain a profile of important minerals, and are a good source of protein, vitamins, $\beta$ - carotene, amino acids and various phenolics (Farooq et al., 2007). The Moringa plant provides a rich and rare combination of zeatin, quercetin, kaempferom and many other phytochemicals. It is very important for its medicinal value. Various parts of the plant such as the leaves, roots, seed, bark, fruit, flowers and immature pods act as cardiac and circulatory stimulants, possess antitumour (Makonnen et al., 1997), antipyretic, antiepileptic, antinflammatory, antiulcer (Pal et al., 1995a). Other important medicinal properties of the plant include antispasmodic (Caceres et al., 1992), diuretic (Morton, 1991), antihypertensive (Dahot, 1988), cholesterol lowering (Mehta et al., 2003), antioxidant, antidiabetic, hepatoprotective (Ruckmani et al., 1998), antibacterial and antifungal activities (Nickon et al., 2003. M. oleifera parts are being employed for the treatment of different ailments in the indigenous system of medicine, particularly in South Asia (Farooq et al., 2007). In addition, M. oleifera seeds possess water purifying powers (Muyibi and Evison, 1995b; Kawo, 2007) by flocculating Gram - positive and Gram - negative bacterial cells (Olsen, 1987; Broin et al., 2002; Kawo, 2007). M. oleifera seeds can also be used as a less expensive bioabsorbent for the removal of heavy metals (Sharma et al. 2006).

Despite this array of uses to which parts of Moringa tree are put to, scanty literature is available on the uses of Moringa oleifera plant parts as sanitizers or preservatives in foods. However, a very important step in the screening of a plant material for sanitizing/preservative activity is to evaluate its antimicrobial activity against food - borne microorganisms (Bukar et al., 2010). The determination of a plant's antimicrobial profile against food - borne microorganisms may promote the plant to further tests geared towards its evaluation as a sanitizer or preservative in foods. 
It is in view of this, that the present research was set up to evaluate the phytochemical constituents and antimicrobial activity of chloroform and ethanol seed and leaf extracts of Moringa oleifera against some food - borne microorganisms. This is with a view to evaluating the plant's potentials for sanitation and/or preservation of foods.

\section{MATERIALS AND METHODS \\ Collection, authentication and processing of plant materials}

The fresh leaf and seed of $M$. oleifera were collected from Dambatta Local Government Area, Kano State, Nigeria. The plant materials were identified and authenticated by a Botanist at the Biological Science Department, Bayero University, Kano, Confirmation of taxonomic identity of the plants was achieved by comparison with voucher specimens kept at the Herbarium of the Department of Biological Sciences, BUK and use of documented literature from Dalziel (1960). The plant materials were air-dried in the laboratory for four weeks and then ground into powdered form, using a mortar and pestel, and stored for future use.

\section{Extraction}

The powdered plant material $(50 \mathrm{~g})$ each of seed and leaf were percolated in $500 \mathrm{~mL}$ chloroform and redistilled ethanol in separate $1 \mathrm{~L}$ capacity conical flasks, stoppered and kept for two weeks with intermittent shaking. The percolates were filtered with Whatman's No 1 filter paper. The extracts were concentrated at $40^{\circ} \mathrm{C}$ under reduced pressure using rotary evaporator (R110). The same quantity of plant material was again percolated with distilled water for one week and after filteration, the aqueous extract was concentrated in hot oven at $40^{\circ} \mathrm{C}$ (Fatope et al., 1993). The concentrated extracts were labeled MLE (Moringa ethanol leaf extract), MSE (Moringa seed ethanol extract), MLC (Moringa leaf chloroform extract) and MSC (Moringa leaf chloroform extract).

\section{Phytochemical Analysis}

Phytochemical analysis for qualitative detection of alkaloids, flavonoids, tannins and saponins was performed on the extracts as described by Trease and Evans (1989), Sofowora (1984).

\section{Test Organisms}

Staphylococcus aureus, Enterobacter aerogenes, Escherichia coli, Salmonella typhi, Salmonella typhimurium, Shigella spp and Pseudomonas aeruginosa were bacteria isolated, while Mucor spp and Rhizopus spp were fungi isolated from food samples, which included rice and beans dish, roselle calyx juice (zobo), fresh tomato, bread, lettuce, carrot and fried groundnut. This was followed by homogenizing and streaking food samples on appropriate media for isolation. Cultural and morphological identification as well as biochemical characterization of isolates using protocols described by Cheesbrough (2002) was carried out. Pure cultures of the isolates were maintained in appropriate media for future use.

\section{Antimicrobial Disc preparation}

Discs of about $6 \mathrm{~mm}$ diameter were made from Whatman's No.1 filter paper using a paper puncher. Batches of 100 discs were transferred into Bijou bottles and sterilized in the oven at $121^{\circ} \mathrm{C}$ for 15 minutes. Stock solution $(400 \mathrm{mg} / \mathrm{ml})$ of the plant extract was prepared by dissolving $0.8 \mathrm{~g}$ of each extract in $2 \mathrm{ml}$ dimethylsulphoxide (DMSO). Serial doubling dilution was carried out by adding $1 \mathrm{ml}$ of DMSO at each serial dilution. Four concentrations were prepared from the stock solution such that each disc absorbed $0.01 \mathrm{ml}$ which was equivalent to 500 $\mu \mathrm{g} /$ disc, $1000 \mu \mathrm{g} /$ disc, $2000 \mu \mathrm{g} /$ disc and $4000 \mu \mathrm{g} / \mathrm{disc}$ respectively.

\section{Standardization of Inoculum}

The inocula were prepared from the stock cultures, which were maintained on nutrient agar slant at $4{ }^{\circ} \mathrm{C}$ and subcultured onto nutrient broth using a sterilized wire loop. The density of suspension inoculated onto the media for susceptibility test was determined by comparison with 0.5 McFarland standard of Barium sulphate solution (Cheesbrough, 2002). Spore suspension for fungal bioassay was prepared according to the procedure of Murugan et al. (1995).

\section{Antimicrobial Assay}

Disc agar diffusion technique described by Bauer et al. (1966) and demonstrated by Cakir et al. (2004) was employed for antibacterial bioassay. For fungi susceptibility testing, the extracts were incorporated into appropriate medium and subsequently fungal spore suspension inoculated. The preparation was incubated at appropriate temperatures. After incubation, zone of inhibition (diameter) formed in the medium was measured to determine antibacterial effectiveness of the different concentrations of the extracts, while sensitivity of the fungi to the test extract was recorded as described by Murugan et al. (2007).

\section{Determination of Minimum Inhibitory \\ Concentration (MIC)}

The minimum inhibitory concentration for bacterial isolates was carried out using tube dilution technique as described by Akinyemi et al. (2005). Stock solution of $80,000 \mu \mathrm{g}$ in $10 \mathrm{ml}$ sterilized distilled water was serially diluted to arrive at concentrations of 500 $\mu \mathrm{g} / \mathrm{ml}, 1000 \mu \mathrm{g} / \mathrm{ml}, 2000 \mu \mathrm{g} / \mathrm{ml}$ and $4000 \mu \mathrm{g} / \mathrm{ml}$.

\section{RESULTS AND DISCUSSION}

Moringa oleifera phytochemical screening revealed presence of flavonoids and saponins in MLE (Table 1). Tannins and saponins were detected in MSE in agreement with report by Napolean et al. (2009). Alkaloids were reported in the present study which was not determined by Napolean et al. (2009). MSC was shown to possess only saponins while MLC contained alkaloids, tannins and saponins, which were not reported by Napolean et al. (2009). 
Farooq et al. (2007) reported that plants occur in varying habitats, a great magnitude of variation in the concentration and composition of phytochemical ingredients in the different parts of such plant is expected. Moreover, Waller and Nowacki (1978) reported that phytochemicals are produced in response to perceived threats by the plants, therefore variation exist in the production of these phytochemicals depending on the type and amount of threat encountered by the plant.

Table 2 presents the results of antibacterial activity of $M$. oleifera extracts on food - borne bacterial isolates. It can be deduced that $M$. oleifera leaf ethanol (MLE) extract had the broadest spectrum of activity on the test bacteria. The results show that it had activity against four bacterial isolates. Enterobacter spp $(07 \mathrm{~mm}), S$. aureus (08), $P$. aeruginosa (07) and $E$. coli (07) were sensitive at concentration of $200 \mathrm{mg} / \mathrm{ml}$, while Shigella spp, $S$. typhi and $S$. typhimurium were not sensitive at all the concentrations used. Napolean et al. (2009) also reported Enterobacter spp, $S$. aureus, $P$. aeruginosa, $S$. typi and $E$. coli to be sensitive to MLE at concentration of $200 \mathrm{mg} / \mathrm{ml}$.

MLC was active on $E$. coli $(08 \mathrm{~mm}), S$. typhimurium $(10 \mathrm{~mm})$ and $S$. typhi $(07 \mathrm{~mm})$ at concentration of $200 \mathrm{mg} / \mathrm{ml}$. Arzai (2008) also reported that MLE and MLC showed activity on $E$. coli, $P$. aeruginosa, $S$. aureus and $S$. typhi. From the results, MLE was observed to be more potent than MLC. This is justified by the report of Ajaiyeoba (2002) who indicated that polar solvents (ethanol and aqueous) extracts were more active than extracts of other non polar or less polar solvents such as chloroform.

Moringa oleifera seed ethanol (MSE) extract was active against three bacterial isolates with $S$. aureus $(10 \mathrm{~mm})$ and $E$. coli $(07 \mathrm{~mm})$ being sensitive to the lowest concentration of $50 \mathrm{mg} / \mathrm{ml}$. S. typhi $(10 \mathrm{~mm})$ was only sensitive to the extract at $200 \mathrm{mg} / \mathrm{ml}$ concentration. Enterobacter spp, Shigella spp, $P$. aeruginosa and $S$. typhi were not sensitive to any of the concentrations tested.

Moringa oleifera seed chloroform (MSC) extract was active against two bacterial isolates with E. coli $(09 \mathrm{~mm})$ and $S$. typhimurium $(09 \mathrm{~mm})$ only sensitive to concentration of $100 \mathrm{mg} / \mathrm{ml}$. Enterobacter spp, $S$. aureus, Shigella spp, $P$. aeruginosa, and $S$. typhi were not sensitive to any of concentrations tested. The results (Table 2 ) show that MSC was the least extract with activity on the tested organisms. Its low antibacterial activity might be linked to its phytochemical contents as the result of phytochemical screening indicated that it possess only saponins. Possession of alkaloids, tannins and flavonoids, which were not detected in MSC extract have been shown to enhance antimicrobial property of a plant as stated by Singh and Bhat (2003) and Tschehe (1971).

The antibacterial properties of the leaf and seed of $M$. oleifera as shown in the present study corroborate the earlier claims by Aktar et al. (2006) and Foidl et al. (2001) who reported on the antibacterial properties of $M$. oleifera seed and leaf. The antibacterial activity of Moringa oleifera seed has been highlighted by many authors (Olsen et al., 1987; Madsen et al., 1987; Kawo, 2007). The antimicrobial activity of $M$. oleifera seed is due to the presence of an array of phytochemiacals, but most importantly due to the activity of a short polypeptide named 4 (a - L - rhamnosyloxy) benzyl-isothiocyanate (Eilert et al., 1981; Guevara et al., 1999). The peptide may act directly on microorganisms and result in growth inhibition by disrupting cell membrane synthesis or synthesis of essential enzymes (Silvestre et al., 2000; Suarez et al., 2003).

Of note is the fact that $P$. aeruginosa was only sensitive to MLE at concentration of $200 \mathrm{mg} / \mathrm{ml}$, indicating that $M$. oleifera extracts tested might have limited effect on the proliferation and activities of $P$. aeruginosa in foods. $P$. aeruginosa is well known as a hardy and difficult organism that constitutes problems to researchers (Brooks et al., 2001).

Various authors have reported antimicrobial activities of plant extracts on food - borne pathogens (Afolabi, 2007; Atiqur Rahman and Sun, 2009; Moreira et al., 2005; Kotzekidou et al., 2007), which indicates the vigorous pursuit in the search for more candidates of plant - derived sanitizers and preservatives.

Table 3 shows the result of antifungal activities of $M$. oleifera extracts on the test fungi. MSC inhibited the growth of Mucor spp and Rhizopus spp by $100 \%$ at $1000 \mu \mathrm{g} / \mathrm{ml}$ while MSE inhibited growth of Mucor spp by $75 \%$ and Rhizopus spp by $50 \%$ each at $1000 \mu \mathrm{g} / \mathrm{ml}$ concentration.

MLC inhibited the growth of Mucor spp and Rhizopus spp by $25 \%$ at $1000 \mu \mathrm{g} / \mathrm{ml}$ while MLE inhibited growth of Mucor spp by $50 \%$ and Rhizopus spp by $100 \%$ each at $1000 \mu \mathrm{g} / \mathrm{ml}$ concentration. Comparatively, it could be observed that MSC proved to be the extract with the best antifungal activity on the test fungi as it prevented completely the growth of both Mucor spp and Rhizopus spp at $1000 \mu \mathrm{g} / \mathrm{ml}$. The standard drug, Ketoconazole inhibited growth of the test fungi at $500 \mu \mathrm{g} / \mathrm{ml}$. The antifungal activities of Moringa seed and leaf have been reported by Nwosu and Okafor (1995), while the seed extract was shown to be active on Rhizopus spp (Raheela et al. 2008).

The antimicrobial activity of the extracts tested, which reveal bioactivity on organisms such as E. coli, S. aureus, P. aeruginosa, S. typhi, $S$. typhimurium and $E$. aerogenes is encouraging as these organisms range from pathogenic and toxigenic organisms liable to cause food - borne illnesses to spoilage-causing organisms liable to spoil food products. The control of these organisms by the extracts in foods would reveal the potentials of these extracts as preservatives. The findings add impetus to the clarion call by consumers and authorities in food industries for the replacement of chemicallysynthesized sanitizers/preservatives with "naturally derived" ones (Jancxsen et al., 2002; Lanciotti et al., 2003). 
Bajopas Volume 3 Number 1 June 2010

Table 1: Phytochemical characteristics of the M. oleifera seed and leaf extracts

\begin{tabular}{lllll} 
Phytochemicals & MSC & MSE & MLC & MLE \\
\hline Alkaloids & - & + & + & - \\
Flavonoids & - & + & - & + \\
Saponins & + & - & + & + \\
Tannins & - & - & + & -
\end{tabular}

Key: $\mathrm{MSC}=M$. oleifera seed chloroform extract, $\mathrm{MSE}=M$. oleifera seed ethanol extract, $\mathrm{MLE}=M$. oleifera leaf ethanol, $\mathrm{MLC}=$ Moringa leaf chloroform,$+=$ present,$-=$ absent

Table 2: Antibacterial Activities of Moringa oleifera seed extracts on food-borne isolates

\begin{tabular}{|c|c|c|c|c|c|c|c|c|}
\hline \multirow[b]{2}{*}{ Extract } & \multirow[b]{2}{*}{ Conc.(mg/ml) } & \multicolumn{7}{|c|}{ Zone of Inhibition (mm) } \\
\hline & & ENT & STA & SHI & PA & EC & STM & ST \\
\hline \multirow[t]{5}{*}{ MSC } & 50 & 06 & 06 & 06 & 06 & 06 & 06 & 06 \\
\hline & 100 & 06 & 06 & 06 & 06 & 09 & 09 & 06 \\
\hline & 200 & 06 & 06 & 06 & 06 & 09 & 09 & 06 \\
\hline & 400 & 06 & 06 & 06 & 06 & 09 & 10 & 06 \\
\hline & $\mathrm{MIC}(\mathrm{mg} / \mathrm{ml})$ & $>4.0$ & $>4.0$ & 2.0 & $>4.0$ & $>4.0$ & 1.0 & 2.0 \\
\hline \multicolumn{9}{|c|}{ E. coli, S. typhimurium (2) } \\
\hline \multirow[t]{5}{*}{ MSE } & 50 & 06 & 10 & 06 & 06 & 07 & 06 & 06 \\
\hline & 100 & 06 & 11 & 06 & 06 & 08 & 06 & 06 \\
\hline & 200 & 06 & 11 & 06 & 06 & 09 & 10 & 06 \\
\hline & 400 & 06 & 11 & 06 & 06 & 09 & 11 & 06 \\
\hline & $\mathrm{MIC}(\mathrm{mg} / \mathrm{ml})$ & 2.0 & 4.0 & $>4.0$ & $>4.0$ & $>4.0$ & $>4.0$ & $>4.0$ \\
\hline \multicolumn{9}{|c|}{ E. coli, S. aureus, S. typhimurium (3) } \\
\hline \multirow[t]{5}{*}{ MLC } & 50 & 06 & 06 & 06 & 06 & 06 & 06 & 06 \\
\hline & 100 & 06 & 06 & 06 & 06 & 06 & 06 & 06 \\
\hline & 200 & 06 & 06 & 06 & 06 & 08 & 10 & 07 \\
\hline & 400 & 06 & 06 & 06 & 06 & 08 & 10 & 08 \\
\hline & $\mathrm{MIC}(\mathrm{mg} / \mathrm{ml})$ & $>4.0$ & $>4.0$ & $>4.0$ & $>4.0$ & 2.0 & 1.0 & 2.0 \\
\hline \multicolumn{9}{|c|}{ E. coli, S. typhi, S. typhimurium (3) } \\
\hline \multirow[t]{6}{*}{ MLE } & 50 & 06 & 06 & 06 & 06 & 06 & 06 & 06 \\
\hline & 100 & 06 & 06 & 06 & 06 & 06 & 06 & 06 \\
\hline & 200 & 07 & 08 & 06 & 07 & 07 & 06 & 06 \\
\hline & 400 & 07 & 09 & 06 & 08 & 08 & 06 & 06 \\
\hline & $\mathrm{MIC}(\mathrm{mg} / \mathrm{ml})$ & 2.0 & 2.0 & 2.0 & $>4.0$ & $>4.0$ & $>4.0$ & $>4.0$ \\
\hline & \multicolumn{8}{|c|}{ E. coli, P. aeruginosa, S. aureus, Enterobacter spp (4) } \\
\hline Control & $30 \mu \mathrm{g}$ & 32 & 30 & 28 & 25 & 30 & 30 & 25 \\
\hline
\end{tabular}

Key: $>=$ greater than, MSC $=$ Moringa seed chloroform, MSE $=$ Moringa seed ethanol, MLC = Moringa leaf chloroform, MLE = Moringa leaf ethanol, $06 \mathrm{~mm}=$ size of disc $\mu \mathrm{g}=$ microgramme, Control $=$ Streptomycin, ENT $=$ Enterobacter aerogenes, $\mathrm{STA}=S$. aureus, $\mathrm{SHI}=$ Shigella $\mathrm{spp}, \mathrm{PA}=P$. aeruginosa, $\mathrm{EC}=E$. coli, $\mathrm{STM}=S$. typhimurium, $\mathrm{ST}=S$. typhi

Table 3: Antifungal activities of different extracts of Moringa oleifera on food-borne isolates

\begin{tabular}{llll}
\hline Extract & Conc. $(\boldsymbol{\mu g} / \mathbf{m l})$ & Mucor spp & Rhizopus Spp \\
MSC & $\mathbf{1 0 0}$ & + & + \\
& $\mathbf{5 0 0}$ & + & + \\
\hline MSE & $\mathbf{1 0 0 0}$ & - & ++++ \\
& $\mathbf{1 0 0}$ & ++++ & ++++ \\
& $\mathbf{5 0 0}$ & ++ & ++ \\
\hline MLC & $\mathbf{1 0 0 0}$ & + & +++ \\
& $\mathbf{1 0 0}$ & ++++ & +++ \\
& $\mathbf{5 0 0}$ & ++++ & +++ \\
\hline MLE & $\mathbf{1 0 0 0}$ & +++ & ++ \\
& $\mathbf{1 0 0}$ & +++ & - \\
\hline Control & $\mathbf{5 0 0}$ & ++ & - \\
\hline Key: MSC $=$ Moringa seed chloroform, MSE = Moringa seed ethanol, MLC = Moringa leaf chloroform, MLE $=$ \\
Moringa leaf ethanol, control $=$ Ketoconazole & ++ \\
$++++=$ normal growth, $+++=25 \%$ inhibition, $++=50 \%$ inhibition, $+=75 \%$ inhibition, $-=100 \%$ inhibition
\end{tabular}




\section{CONCLUSION AND RECOMMENDATION}

The results of the present study have shown the potentials $M$. oleifera chloroform and ethanol extracts possess as sanitizers/preservatives. This is due to the fact that they were found to possess antimicrobial

\section{REFERENCES}

Afolabi, F.E. (2007): Chemical composition and antibacterial activity of Gongrenema latifolium. Journal of Zhejiang University Science. 8(5): $352-358$.

Ajaiyeoba, E. (2002): Phytochemical and antibacterial properties of Parkia biglobosa and P. bicolor leaf extracts. African Journal of Biomedical Research 5(1): 125 - 129.

Akhtar, M., Hassany, S.M., Bhanger, M.I., Iqbal, S. (2006): Absorption potential of $M$. oleifera pods for the removal of organic pollutants from aqueous solutions. Journal of Hazardous Materials. In print.

Akinyemi, K.O., Oladapo, O., Okwara, C.E., Ibe, C.C. and Fasure, K.A. (2005): Screening of crude extracts of six medicinal plants used in South West Nigerian unorthodox medicine for antimethicillin resistant $S$, aureus activity. $B M C$ Complimentary Alternative Medicine. 5:6

Arzai, A.H. (2008): Detection of $\beta$-lactamase producing microorganisms and their susceptibility to selected antibiotics and medicinal plant extracts. PhD thesis submitted to the Department of Biological Sciences, Bayero University, Kano.

Atiqur, R. and Sun, C. K. (2009): In vitro control of food - borne and food spoilage bacteria by essential oil and ethanol extracts of Lonicera japonica Thunb. Food Chemistry, 116(3): 670 $-675$.

Bauer, A.W., Kirby, W.M., Sherris, J.C. and Turck, M. (1966): Antibiotic susceptibility testing by a standardized single disk method. Am. J. Clin. Pathol. 45(4): 493 - 496.

Broin, M., Santaella, C., Cuine, S., Kokou, K., Peltier, G. and Joet, T. (2002): Flocculent activity of a recombinant protein from Moringa oleifera Lam. Seeds. Appl. Microbiol. Biotechnol. 60:114 119.

Brooks, G.F., Butel, J.S. and Morse, S.A. (2001): Jawetz, Melnick and Adelberg's Medical Microbiology (22 ${ }^{\text {nd }}$ edn.). Lange Medical Books. Pp. $145-150$

Bukar, A., Uba, A. and Oyeyi, T.I. (2010): Phytochemical analysis and antimicrobial activity of parkia biglobosa (Jacq.) Benth. extracts against some food - borne microorganisms. Advances in Experimental Biology (In press)

Caceres, A., Saravia, A., Rizzo, S., Zabala, L., Leon, E.D. and Nave, F. (1992): Pharmacological properties of Moringa oleifera 2: Screening for antispasmodic, anti-inflammatoy and diuretic activity. J. Ethnopharmaco/36:233 - 237.

Cakir, A., Kordali, S., Zengin, H., H. Izumi, S. and Hirata, T. (2004): Composition and antifungal activity of essential oils isolated from activities against some food - borne microorganisms often implicated in the spoilage of foods and food borne illnesses. Further research should be conducted to test the sanitizing and preservative effect of the extracts on some foods.

Hypericum hussopifolium and $H$. heterrophyllum. Flavour Frag. J. 19:62 - 68.

Cheesbrough, M. (2002): Medical laboratory manual for tropical countries. ELBS edition. Tropical health technology publications, UK. 2:2-392.

Dahot, M.U. (1988): Vitamin contents of flowers and seeds of M. oleifera. Pak. J. Biochem. 21:1 24.

Dalziel, J.M. (1916): A Hausa Botanical Vocabulary. T. Fisher Unwin Ltd, London. Pp. 5 - 167.

Eilert, U., Wolters, B. and Nadrtedt, A. (1981): The antibiotic principle of seeds of Moringa oleifera and Moringa stennopetala. Planta Med. 42:55 51.

Farooq, A., Sajid, L., Muhammad, A. and Anwarul Hassan, G. (2007): Moringa oleifera: a food plant with multiple medicinal uses. Phytotherapy Research. 21:17 - 25.

Fatope, M.O., Ibrahim, H. and Takeda, Y. 1993. Screening of higher plants reputed as pesticides using the Brine Shrimp Lethality Assay. Int. J. Pharmacog. 31(4):250 - 254.

Foidl, N., Makkar, H.P.S. and Becker, K. (2001): The potential of Moringa oleifera for agricultural and industrial uses. In: "The miracle tree (Ed Lowell, J.F.) CTA, USA.

Guevara, A.P., Vargas, C. and Sakurai, H. (1999): An antitumor promoter from $M$. Oleifera Lam. Mutat. Res. 440:181 - 188.

Jancxsens, L., Devlieghere, F. and Debevere, J. (2002): Temperature dependence of shelf - life as affected by microbial proliferation and sensory quality of equilibrium modified atmosphere packaged fresh produce. Postharvest Biol. Technol. 26:59 - 73.

Kawo, A.H. (2007): Water purification potentials and in-vivo toxicity evaluation of the aqueous and petroleum ether extracts of Calotropis procera (Ait.F) Ait.F. latex and Moringa oleifera Lam seed powder. PhD thesis, Microbiology Unit, Department of Biological Sciences, Bayero University, Kano. 184pp.

Kotzekidou, P., Giannakidis, P. and Boulamatsis, A. (2007): Antimicrobial activity of some plant extracts and essential oils against foodborne pathogens in vitro and on the fate of inoculated pathogens in chocolate $\angle W T$ - Food Science and Technology 41(1):119-127

Lanciotti, R., Patrignani, F., Bagnolini, F., Guerzoni, M.E. and Gardini, F. (2003): Evaluation of diacetyl antimicrobial activity against $E$. coli, $L$. monocytogenes and $S$. aureus. Food Microbiol. 20:557 - 543

Madsen, M., Schlunt, J. and Omer, E. (1987): Effect of water coagulation by seeds of Moringa oleifera on bacterial concentration. J. Trop. Med. Hyg. 90:101 - 109. Makonnen et al., 1997 
Makonnen, E., Hunde, A. and Damecha, G. (1997): Hypoglycaemic effect of $M$. stenopetala aqueous extract in rabbits. Phytother. Res. $11: 147-148$.

Mehta, L.K., Balaraman, R., Amin, A.H., Baffa, P.A. and Gulati, O.D. (2003): Effects of fruits of $M$. oleifera on the lipid profile of normal and hypercholesterolaemic rabbits. $J$. Ethnopharmacol. 86:191 - 195.

Moreira, M.R., Ponce, A.G., del Valle, C.E. and Roura, S.I. (2005): Inhibitory parameters of essential oils to reduce a food-borne pathogen. LWT - Food Science and Technology 38(5): 565-570Morton, 1991

Morton, J.F. (1991): The horse radish tree: $M$. pterigosperma (Moringacea). A boon to arid lands. Economic Botany. 45:318 - 333.

Mughal, M.H., Ali, G., Srivasta, P.S. and Iqbal, M. (1999): Improvement of drumstick ( $M$. pterygosperma Gaertn) - a unique source of food and medicine through tissue culture. Harmdad Med. 42:37 - 42.

Murugan, S., Anand, R. Uma Devi, P., Vidhya, N. and Rajesh, K.A. (2007): Efficacy of Euphobia milli and $E$. pulcherrima on aflatoxin producing fungi (Aspergillus flavus and $A$. parasiticus). African Journal of Biotechnology. 6(6):718 719.

Muyibi,, S.A. and Evison, L.M. (1995b): Optimizing physical parameters affecting coagulation of turbid water with $M$. oleifera seeds. Water. Res. 29:2689 - 2695.

Napolean, P., Anitha, J. and Emilin, R.R. (2009): Isolation, analysis and identification of phytochemicals of antimicrobial activity of Moringa oleifera Lam. Current Biotica. 3(1): $33-37$

Nickon, F., Saud, Z.A., Rehman, M.H. and Haque, M.E. (2003): In vitro antimicrobial activity of the compound isolated from chloroform extract of M. oleifera Lam. Pak. J. Biol. Sci. 22:1888 -1890 .

Nwosu, M.O. and Okafor, J.I. (1995): Preliminary studies on the antifungal activities of some medicinal plants against Basidiobolus and some other pathogenic fungi. Mycoses 38:191 - 195 .

Olsen, A. (1987): Low technology water purification by bentonite clay and $M$. oleifera seed flocculation as performed in Sudanese villages: effects on Schistosoma mansoni cercariae. Water Res. 21: 517 - 522.

Pal, S.K., Mukherjee, P.K. and Saha, B.P. (1995a): Studies on the antiulcer activity of $M$. oleifera leaf extract on gastric ulcer models in rats. Phytother. Res. 9:463 - 465.

Raheela, J., Muhammad, S., Jamil, A. and Muhammad, A. (2008): Microscopic evaluation of the antimicrobial activity of seed extracts of M. oleifera. Pak. J. Bot. 40(4): $1349-1358$.

Rebecca, H.S.U., Sharon, M., Arbainsyah, A.and Lucienne, D. (2006): Moringa oleifera: medicinal and socio-economic uses. International Course on Economic Botany. National Herbarium Leiden, Netherlands. Pp. $2-6$.

Ruckmani, K., Kavimani, S., Anandan, R. and Jaykar, B. (1998): Effect of Moringa oleifera Lam on paracetamol - induced hepatoxicity. Indian J. Pharm. Sci. 60:33 - 35.

Sharma, P., Kumari, P., Srivastava, M.M. and Srivastava, S. (2006): Removal of cadmium from aqueous system by shelled $M$. oleifera Lam. seed powder. Bioresource Technology. 97:299 - 305

Silvestro, L., Weiser, J.N.and Axelsen, P.H.(2000): Antibacterial and antimembrane activities of cepropin A in Eschericchia coli. Antimicrob. Agents Chemother. 44:602 - 607.

Singh B. and Bhat T. K. (2003): Potential therapeutic applications of some antinutritional plant secondary metabolites. Journ. Agric. Food Chem. 51:5579-5597

Sofowora, E.A. (1984). Medicinal and Traditional Medicine in Africa. John Wiley and Sons, London. 249pp.

Somali, M.A., Bajnedi, M.A. and Al-Faimani, S.S. (1984): Chemical composition and characteristics of $M$. peregrine seeds and seed oil. J. Am. Chem. Sco. 61:85-86.

Suarez, M., Entenza, J.M. and Dorries, C. (2003): Expression of a plant - derived peptide harbouring water - cleaning and antimicrobial activities. Biotechnol. Bioeng. $81: 13-20$

Trease, G.E. and Evans, W.C. (1989): Pharmacognosy. $15^{\text {th }}$ edition. Lea and Fabiger, Philadepia.

Tscheche, R. (1971): Advances in the chemistry of antibiotic substances from higher plants: Pharmacognosy and phytochemistry. In proceeding of $1^{\text {st }}$ International Congress, Munich, 1970: 274-289

Waller, G.R. and Nowacki, E.K. (1978): Role of alkaloids. Alkaloid Biology and Metabolism in Plants. Plenus Press, New York. 249pp. 